\title{
What Ever Happened to My Peace of Mind? Hag Horror as Narrative of Trauma
}

\section{ABSTRACT}

In his pioneering study of Grande Dame Guignol (also referred to as hag horror or psycho-biddy), a female-centric 1960s subgenre of horror film, Peter Shelley explains that the grande dame, a stock character in this form of cinematic expression, "may pine for a lost youth and glory, or she may be trapped by idealized memories of childhood, with a trauma that haunts her past” (8). Indeed, a typical Grande Dame Guignol female protagonist/antagonist (as these two roles often merge) usually deals with various kinds of traumatic experiences: loss of a child, domestic violence, childhood abuse, family conflicts or sudden end of career in the fickle artistic industry, etc. Unable to cope with her problems, but also incapable of facing the inevitable process of aging and dying, she gradually yields to mental and physical illnesses that further strengthen the trauma and lead to her social exclusion, making her life even more unbearable. Unsurprisingly, scholars such as Charles Derry choose to name psycho-biddies horrors of personality, drawing attention to the insightful psychological portrayal of their characters. Thus, it would be relevant and illuminating to discuss films such as Die! Die! My Darling! (1965) and Whoever Slew Auntie Roo? (1971) as narratives of trauma. This will be the main concern of my article.

Keywords: Grande Dame Guignol, hag horror, trauma theory, Gothic. 
Grande Dame Guignol, also known as hag horror or psycho-biddy, frequently explored the theme of trauma turning the lives of its characters into nightmare. Hag horror, a fairly short-lived cinematic fad, emerged in the early 1960s. ${ }^{1}$ It drew inspiration from the Gothic tradition dating back to the mid- $18^{\text {th }}$ century and the $19^{\text {th }}$-century theatrical phenomenon, i.e. Le Thêâtre du Grand-Guignol, specializing in naturalistic and exploitative gory performances. Peter Shelley, the author of a seminal work on this genre, defines Grande Dame Guignol as "a horror movie which uses grand guignol effects and stars an actress in a leading role playing a character with the airs and graces of a grande dame" (3). The Grande Dame, a stock character in this form of cinematic expression, "may pine for a lost youth and glory, or she may be trapped by idealized memories of childhood, with a trauma that haunts her past" (Shelley 8). Typically, a female protagonist/antagonist deals with various kinds of traumas-from the sudden end of her career (as in Robert Aldrich's 1962 What Ever Happened to Baby Jane? and Donald Wolfe's 1970 Savage Intruder) and marital infidelity (Strait-Jacket, 1964, dir. William Castle) to false accusations of murder and subsequent ostracism (as exemplified by Hush ... Hush, Sweet Charlotte, 1964, dir. Robert Aldrich). Unable to deal with her problems, but also struggling to face the inevitable process of aging and dying, she gradually succumbs to mental and physical illnesses that strengthen the trauma and lead to her social exclusion, making her life even less tolerable. Hence, it is logical to view hag horrors through the lens of trauma theory. Stef Craps defines this approach as "a product of the so-called ethical turn affecting the humanities" which "infuses[s] the study of literary and cultural texts with new relevance" (45). Although trauma theory is usually applied to discuss the aftermath of events such as wars, mass killings or terrorist attacks (e.g., to analyze the testimonies of Holocaust or 9/11 survivors), it can be employed on a more personal level as well, embracing what E. Ann Kaplan labels "suffering terror," "family trauma" and "quiet trauma" (1) to identify different aspects

1 Scholars sometimes use one more term to refer to this trend, i.e. hagsploitation movement, thus suggesting its close ties with other exploitation genres popular between 1950s and 1970s-nunsploitation, blacksploitation, sexploitation, giallo, etc., all of them being cinematic equivalents of yellow press and pulp fiction which used to be frequently associated with Gothicism. David Roche defines exploitation cinema as "an industry with a specific mode of production" rather than a genre, "made cheap for easy profit," "relying on timetried formulas" and offering their audience "sex, violence and taboo topics" (1). I argue that Grande Dame Guignol, despite its eventual descent into the run-ofthe-mill stylistics, offers more than lurid material such as "sex, drugs, vice, nudity, and anything to be considered in 'bad taste"' (Mathijs and Sexton 147). 
of trauma in general, in real life, but also in literature and, more and more frequently, cinema. Films, horror ones among them, "previously excluded from consideration as representations of . . . trauma, actually provide the means to recast key theoretical impasses in film studies, as well as trauma studies" (Lowenstein 1-2). According to Linnie Blake, horror films constitute "a disturbing, yet highly political and therapeutic genre that capacitates its audience to deal with the traumatic legacies and horrific incidents of reality in a productive way, on both an individual and collective level" (qtd. in Elm, Kabalek and Köhne 13). Grande Dame Guignol serves here as an appropriate example.

Although numerous features of the genre had already been displayed by such films as Sunset Boulevard (1950, dir. Billy Wilder) or Les Diaboliques (1955, dir. Henri-Georges Clouzot), it was the aforementioned What Ever Happened to Baby Jane? by Robert Aldrich (1962) that not only marked the beginning of hag horror as such, but also illustrated its specificity, being a conflation of high camp aesthetics, Gothic excess, superfluous theatricality, boundless nostalgia for the Golden Era of Hollywood, and strong interest in the theme of trauma and its consequences. ${ }^{2}$ Indeed, the plot of Baby Jane revolves around the Hudson sisters, two former actresses, and their love-hate relationship, strained even further by the fact that one of them is paraplegic and the other has to unwillingly perform the role of carer (even if she herself is the one in need of professional psychiatric help). However, I decided not to analyze this film, finding it too obvious a choice. Instead, my focus shifted to two British responses to hag horror, both of them dealing with a particular subtype of trauma-one resulting from the loss of a child (even though the theme of trauma related to aging is also prominent in both cases). They are Silvio Narizzano's Die! Die! My Darling!, a 1965 product of the legendary Hammer Studios, as well as Whoever Slew Auntie Roo? (also known as Who Slew Auntie Roo? or The Gingerbread House), a mild horror flick from 1971, directed by Curtis Harrington.

2 According to Charles Derry, hag horror is a subtype of horror of personality and "a psychological study of two women whose relationship was based on some past crime, yet a study that dealt very overtly with the ambiguity of insanity" (33). As such, it marks a clear departure from horror films that dominated the $1940 \mathrm{~s}$ and 1950s-monster movies or mad scientist thrillers. "What seems to have been adopted in the early sixties in these horror films (however sometimes skeptically) was the psychological explanation. Violence and horror were not explained in terms of science or religion, but in terms of psychology. This is made obvious by the very Freudian Oedipal complex in Psycho, the recurring Electra complexes in the Aldrich films, and the obsession with sex in all the films from Psycho to Maniac to Strait-Jacket to Berserk to Orgasmo" (Derry 24). 
The former was originally shown in theatres in 1965 under the notso-catchy title Fanatic. Yet, upon its release onto the American market, it was changed to Die! Die! My Darling!, so as to gain more recognition and to better fit the hagsploitation trend of question and exclamation marks in titles. ${ }^{3}$ Viewers were additionally attracted by the final silver screen appearance of Tallulah Bankhead, a Hollywood icon of the 1930s and 1940s, who agreed to perform in the film after a 20 -year hiatus from cinema. Bankhead returned as the deranged Mrs Trefoile, accompanied by a young Stefanie Powers in the role of the abducted and tortured Patricia Carroll. The movie met with mixed reviews (as was the case with most Grande Dame Guignol productions). In The Aurum Film Encyclopedia of Horror Phil Hardy suggests that Silvio Narizzano, the film's director, "tends to lapse into gratuitous baroqueries" (72). Yet, he agrees that " $[\mathrm{t}]$ he mad Mrs. Trefoile is extravagantly played by Bankhead determined to best Bette Davis's Baby Jane. Powers's change from mild amusement to sheer terror and Bankhead's development from eccentricity to homicidal mania are handled with consummate skill by the two actresses" (Hardy 72). On the other hand, Gary A. Smith applauds Richard Matheson's "wry script," regarding the film "a highly entertaining offering" (98). Its weaknesses notwithstanding, Die! Die! My Darling! merits attention as a unique mixture of camp, horror and religion, but, most of all, as a film in which traumatic experiences play a significant part in propelling the action. Furthermore, it offers a new take on the issue of dramatic familial conflict between two women, since hag horrors hardly (if ever) focused on mother-in-law/daughter-in-law relations before, preferring to exploit the decay of more conventional bonds of kinship such as mother-daughter (e.g., Strait-Jacket), sisters (What Ever Happened to Baby Jane?) or cousins (Hush... Hush, Sweet Charlotte) instead.

The film tells the story of Patricia Carroll, a snobbish city girl who decides to pay a visit to her late lover's mother. She finds it a prerequisite to calm her feeling of guilt as she is going to marry another man, named Alan. She has never met Mrs Trefoile before, therefore she does not realize that Stephen's (i.e. the late husband-to-be) suicide may have resulted from his mother's overbearing behaviour. From the outset, the visit is strange, but Patricia agrees to stay overnight and participate in a mass in memory of Stephen. However, her confession that she intends to marry Alan results in Mrs Trefoile's outburst of exasperation. Enraged, the elderly woman decides to abduct Patricia and keep her in confinement until she repents for

3 According to Howard Maxford, the film was retitled "much to Bankhead's chagrin ... so as to better tie in with her well-known but by now despised affectation for calling everybody darling (drawled as dab-ling)” (266). 
her sin of neglecting Stephen. Although Mrs Trefoile initially calls Patricia "my poor Stephen's love," she quickly changes her mind and blames her for Stephen's untimely death. Mrs Trefoile tries to find solace in religion, but excessive piety verging on fanaticism in fact reinforces her trauma. She is also traumatized by a strong feeling of shame for her own sinful past when she was an actress. As a result, the elderly woman suffers a nervous breakdown and obsessively seeks an opportunity to avenge her son's death. Thus, she immediately assumes a specific role for her daughter-inlaw-to-be: that of a fallen woman in need of a thorough moral cleansing. In addition, Mrs Trefoile and Patricia can be viewed as modern renditions of the tyrant and damsel in distress, a stock binary opposition to be found in numerous Gothic stories. ${ }^{4}$

Similarly to other hag horrors, the audience is confronted with a spectacular struggle between two strong-willed, independent women, even if one of them is clearly at a disadvantage. Their duel is enhanced by the Gothic setting (a threatening dark house with barred windows) and the presence of three ominous-looking servants: Harry, a butler and the only living relative of Mrs Trefoile; Anna, his obedient wife; and Joseph, their mentally disabled son. Although the complex Patricia-Mrs Trefoile relationship forms the core of the plot, one cannot fail to notice the ambiguous role of the background characters, especially Anna and Harry. Throughout the film, these two passively obey Mrs Trefoile's orders and become her accomplices in abducting and forcefully keeping Patricia in the house. Undoubtedly, the Gothic manor and its inhabitants immediately make one think of the stereotypical image of a den where "the weirdos live ..., the cultish families with the disgusting habits [and] the serious lack of regard for the ways of . . . normal upstanding citizens" (Penner, Schneider and Duncan 37). All of the above contribute to the film's nightmarish campiness.

Mrs Trefoile's exuberant religious zeal also adds to the movie's camp aesthetics. The woman confesses that she reads the Book of Scriptures "each night and each morning," as it gives her a profound sense of freedomespecially from the traumatic memories of her career as an actress and immorality she associates with it. Mrs Trefoile's equivocal attitude to

4 Since its inception, Gothic fiction was replete with traumatic events, from family loss (e.g., Horace Walpole's 1764 The Castle of Otranto, Ann Radcliffe's 1794 The Mysteries of Udolpho, Mary Shelley's 1818 Frankenstein; Or, the Modern Prometheus) to rape and murder (as in The Monk by Matthew Gregory Lewis, 1796). The aforementioned tyrant-damsel conflict would be either a direct consequence of such a dramatic event or a further source of trauma (most of all, for the damsel), or, in the majority of cases, both. See Hogle. 
her former profession is evident throughout the film. In one of the early scenes, Patricia enters Mrs Trefoile's private chamber where she notices an album filled with photo stills, all of which portray the latter in her youth (Narizzano here uses real-life photographs of Tallulah Bankhead in her Hollywood prime). Mrs Trefoile, unable to conceal her wrath, explains that they remind her of what she had been before she entered the road to salvation and transformed into a deeply spiritual person:

God was good. He led me from that evil. Yes. A pit of evil! A place for the lost and the damned! The devil's entertainment! God's anathema! It is a painful memory to me, but by the grace of our Lord and the inspiration of my late husband, no more than a memory. I keep it as a harsh reminder of what I was, of what I escaped!

Her speech at least partially clarifies why she expects a similar sacrifice from Patricia, in whom she sees the former sinful version of herself. Therefore, Mrs Trefoile buries herself in her own perverted vision of piety, which helps her to live in denial after the tragic loss of her son and to come to terms with the inevitability of death.

Her fanaticism manifests itself in many ways. She insists on continual praying and reading the Bible aloud. As a result of a conflict with the local vicar, she performs lengthy masses at home herself. Many objects must not be used in her house-there is no radio, TV set, telephone, not to mention mirrors ("A mirror? Is it to adorn yourself, to observe yourself? Mirrors are naught but tools of vanity, Patricia. I know! Vanity—sensuality, Patricia! The Bible speaks of our vile bodies."). Restrictions apply even to food ("We use no condiments of any kind in this house, Patricia! God's food should be eaten unadorned.").

Moreover, Mrs Trefoile is unhealthily preoccupied with the colour red which she constantly refers to as "scarlet" to underline its evil connotations (and which is a direct allusion to Nathaniel Hawthorne's 1850 novel, The Scarlet Letter). Even though Patricia is no Hester Prynne forced to wear a scarlet A to imply adultery, she is nevertheless perceived as an unfaithful woman by her would-be mother-in-law, who is convinced that Patricia betrayed Stephen, at least spiritually. To prove it, she goes so far as to ask Patricia whether she is still "pure and virgin," this scene accompanied by the suggestive usage of a red filter. The conclusion is clear-scarlet brings to mind everything classifiable as sinful or abject, both bodily and morally. Hence, Patricia is forbidden to use "filthy" lipstick or wear her favourite red garments. At the same time, Mrs Trefoile, a woman ostensibly avoiding scarlet things, not infrequently yields to her innermost desire to bask in red, hanging red curtains in her secret room or keeping a portrait of her 
late son where his shirt is distinctly red, as well. Peter Shelley adds that " $[t]$ he red interior of Patricia's suitcase can also be considered as a vaginal wall, since sexuality is [what] Mrs Trefoile denies herself, with her love of God as an alternative to any love interest" (68). Red is also a significant element of the most powerful scene in this production.

The sequence depicts Mrs Trefoile immediately after she has murdered Harry, the disobedient servant. She slowly ascends the stairs, exposing her blood-covered hands. Besides direct references to Shakespeare's Lady Macbeth, the scene emphasizes the inner split in Mrs Trefoile, her mind being a battlefield where self-imposed religious rigour and desire for the forbidden clash. Later on she is seen wailing on the floor, surrounded by the paraphernalia of pleasure, namely a red lipstick, a mirror and a bottle of alcohol. ${ }^{5}$ Mrs Trefoile turns into a heart-rending travesty of a Grande Dame when she smears the lipstick all over her face and tries to fasten her dishevelled hair. This scene very much resembles the dramatic breakdown of Baby Jane Hudson in front of a mirror in What Ever Happened to Baby Jane? Mrs Trefoile, just like Jane, seems unable to accept her deterioration. The past keeps haunting her, yet in her case there is more than just longing for regaining her youthful looks. She also yearns for her beloved son and therefore immerses herself in religious fanaticism in order to survive. ${ }^{6}$

The lipstick scene cruelly portrays the woman's descent into madness. Obsessed with her son's death, she thinks she hears his voice. The voice instructs her to subject Patricia to various abuses in order to purify her soul and, simultaneously, take revenge for Stephen's death. As The Terror Trap website specializing in horror films produced between 1925 and 1987 notes:

[Patricia is] deprived of food, shot at, and in one scene, accidentally gets stabbed with a pair of scissors during a struggle. Finally, as Pat's future husband is closing in on them, Mrs Trefoile takes Pat down to her basement where she plans to sacrifice her in a makeshift altar to her dead son. ("Ladies of the Grand Guignol")

5 Once again, the onscreen and real life trauma of aging and decline intertwine. "A noted beauty of her day famous for her bright red lipstick, Bankhead played the role without full make-up, giving her appearance a harsh, scrubbed look, which must have been hard for her to bear while playing opposite the applecheeked Powers" (Maxford 265-66).

6 In the introduction to a comprehensive study on trauma entitled Trauma: Explorations in Memory, its editor, Cathy Caruth writes that " $[\mathrm{t}] \mathrm{o}$ be traumatized is precisely to be possessed by an image or event" (4-5). Mrs Trefoile's and Auntie Roo's cases confirm it. 
The former deeply believes in the success of her fight for purity, claiming that "[it] is necessary to make a sacrifice. Sometimes this is the only way." Paradoxically, to achieve this, she has to commit several crimes. Peter Shelley observes that Mrs Trefoile's "fascination with Patricia's blood presents her as a vampire, and the sight of the scissors in Patricia's shoulder is [thus] first grand guignol moment" (70).

Overall, despite its uninhibited campness and horror ambiance, Die! Die! My Darling! successfully tackles the themes of trauma, affliction and sexual repression. A similar statement could be applied to another hag horror, i.e. Whoever Slew Auntie Roo?, even though the film approaches grief and suffering in a more subdued way. Curtis Harrington's 1971 production, starring two-time Academy Award winner Shelley Winters, marks the moment of the genre's decline in popularity. ${ }^{7}$ Nonetheless, it offers an interesting portrait of a middle-aged woman who, in a desperate attempt to come to terms with her young daughter's death, resorts to kidnapping. As a result, a specific bond between the eponymous character and her substitute daughter is established. The film is ripe with crossreferences to classic fairytales and other literary texts, incorporating elements of the horror and camp typical of Grande Dame Guignol style. However, some of the formal solutions adopted by the filmmakers may appear unnecessary and grotesque.

One of them is the opening scene, in which an elegant woman in her early 50 s sings a lullaby to a child rocking in the cradle. Soon the audience learns that the child is in fact a gruesome skeleton dressed in an elaborate Victorian outfit. ${ }^{8}$ Later, the action moves swiftly to an annual Christmas party organized by Mrs Forrest, i.e. the titular Auntie Roo. Mrs Forrest, an unsuccessful ex-vaudeville actress and a widow to a magician, holds regular Christmas celebrations for orphaned children. This is her method to cope with the tragic death of her own daughter Katharine. One of the young guests names Mrs Forrest's mansion "the gingerbread house," which foreshadows future events and points directly to one of the movie's main intertexts, namely the story of Hansel and Gretel, and their encounter

7 Unsurprisingly, Whoever Slew Auntie Roo? garnered ambivalent reviews. Craig Butler notes that "the screenplay doesn't really take advantage of the premise to come up with more than a handful of imaginative twists. It's also poorly structured in places, with characters who are introduced and seem as if they will play an important role, but then just fade away." Gary A. Smith calls Winters's performance "shrill and overwrought" (237). At the same time, scholars such as James Morrison praise the film's "comedy and horror collaps [ing] into one another, exchanging places in syncopation with sudden, inexplicable shifts among expressions of love, hostility, and aggression between generations" (134).

8 James Morrison considers it "a reversal of the Psycho template" (134). 
with the witch. Indeed, the Forrest mansion, with its lavishly decorated spacious rooms, secret passages, traps, hidden doors and a dumb waiter joining the key parts of the building, overtly displays fairytale-like Gothic quality. ${ }^{9}$ Such a specific construction of the house enables Mrs Forrest to keep the mummified remains of her child in a concealed nursery near the loft (the room is situated behind both a mirror and a spacious wardrobeCurtis Harrington seems to have derived inspiration from The Narnia Chronicles by C. S. Lewis). Auntie Roo's daughter died in very unusual circumstances, falling off the bannister which her mother allowed her to slide down. Not unexpectedly, her shocking instant death evokes an acute sense of guilt and causes irreversible mental damage in Mrs Forrest. Similarly to Mrs Trefoile, Auntie Roo, traumatized and shattered, lives in almost complete seclusion, accompanied only by two servants who trick her out of money. Additionally, from time to time she is visited by a fake medium who organizes special séances just for her. Moments of joy are few and far between, and they are usually associated with the aforementioned yuletide parties.

During one of them Mrs Forrest notices little Katy who bears a striking resemblance to the deceased daughter, not only visually, but even in her very name. Mrs Forrest wants to convince Katy to stay by her side. That is why she pays special attention to her whims and showers the girl with gifts. As Katy fails to resist the attention Auntie Roo pays to her, the latter, in a fit of passion, decides to keep Katy by force in her mansion and locks her in the room that once belonged to Katharine (comparisons to Die! Die! My Darling! seem perfectly justified here). At first, Katy sees nothing wrong in being trapped and believes she is merely a partner in a game of hide and seek. Apparently, she accepts Auntie Roo as her new mother and revels in the current situation - not only having a room of her own, but also an abundance of toys. However, the intervention of Christopher, Katy's elder brother, ruins this harmonious union. Christopher, having successfully sneaked into the house, manages to convince his sister that she is in fact being kept imprisoned by a wicked witch who is going to devour both of them. From this moment on, Katy starts to turn against her new mother. In a similar way to Hansel and Gretel, Katy and Chris escape the mansion and set fire to it. In a sequence of events reminiscent of the $17^{\text {th }}$-century

9 Charles Derry points out that a fear-inducing location, such as the dark imposing house, is central to hag horrors, its dilapidation reflecting the mental state of its inhabitants. "Usually the house is a dead thing, containing memories, corpses, or reminders of an old way of life; the horror usually arises because, while the times change, the house and its occupants do not—such as in Baby Jane, Sreet Charlotte, Auntie Roo, and Psycho" (Derry 47). 
Salem trials, the woman falsely accused of witchcraft burns, killed by those in whom she invested so much affection. Katy, though, does not appear to show much concern for her foster mother and smiles derisively as she leaves the house with a teddy bear stuffed with Auntie Roo's jewellery. "She would eat us later," Christopher says, ensuring the rightness of their mutual decision.

Although it is debatable whether Auntie Roo deserved such a severe punishment for the abduction of Katy, there is no denying that, from the opening of the film, it is not so subtly implied that sooner or later her unstable behaviour resulting from her traumatic experiences will lead to a tragic conclusion. Mrs Forrest's over-the-top demeanor, hysterical mood swings, reliance on mediums, extravagant theatrical dresses, and grotesque "transitions from faux crying to laughter" (Shelley 185) reinforce her image as a mad woman, thereby placing her in the role of a threatening Other whose trauma directly affects another person. ${ }^{10}$ One of the most memorable scenes portrays Auntie Roo devouring an apple, thus "bring[ing] to mind images of a witch, specifically the witch from Snow White who traded in apples" (Shelley 185). John Kenneth Muir indicates the Dickensian touch in the construction of the story's protagonistsKaty and Christopher resemble the characters in Oliver Twist, whereas Auntie Roo draws heavily from Great Expectations' Miss Havisham (153).

The reference to Miss Havisham seems pertinent, for Auntie Roo is as tragic and lonely a character as her literary predecessor. One of the film's final scenes confirms the connection. Mrs Forrest visits her late daughter's room and tries to hug the corpse. The dried skull literally crumbles, poignantly signalling that Auntie Roo's world has fallen apart, too. The desperate woman cries "I have nothing!" and the audience realizes how truthful this statement is. Hopeless, helpless, abandoned by the servants and by Katy, but also racked by feelings of guilt, as she considers herself responsible for Katharine's tragic accident, she dies, similarly to Miss Havisham, in flames.

As demonstrated above, devastating denouements characterize most Grande Dame Guignol stories. However dramatic it may sound, hag horror heroines' lives are generally fraught with traumatic events and they end in an equally traumatic way. The eponymous character of What

10 E. Ann Kaplan emphasizes the necessity "to distinguish the different positions and contexts of encounters with trauma," differentiating between direct trauma victims and, for instance, "those who encounter trauma through accounts they hear" (2). Both Katy in Whoever Slew Auntie Roo? and Patricia in Die! Die! My Darling! are indirect victims of those who suffered a particular kind of trauma at first-hand. 
Ever Happened to Baby Jane? faces arrest for life-threatening misconduct towards her sister, Blanche. A similar fate (i.e. life imprisonment in a mental institution) awaits Charlotte Hollis in Hush . . Hush, Sweet Charlotte. Mrs Trefoile is killed, most probably by her servant, Anna, while Mrs Forrest burns to death. What is more, in all cases certain disturbing past experiences unfailingly affect the present. In the case of the Hudson sisters, their childhood conflict, fuelled by envy, continues until their last minute reconciliation. The protagonists (antagonists?) of Die! Die! My Darling! and Whoever Slew Auntie Roo? suffer from the loss of their children, which finally leads them towards criminal activity-abduction, physical and mental abuse, even murder. Therefore, it is unfair to dismiss Grande Dame Guignol as merely camp fun, because camp is just a façadeunder the surface of excessive theatricality and grotesque lies a number of tragedies and traumas.

\section{Works CiTED}

Butler, Paul. Rev. of Whoever Slew Auntie Roo?, by Curtis Harrington. Allmovie.com. AllMovie. Web. 20 May 2019.

Caruth, Cathy. "Trauma and Experience: Introduction." Trauma: Explorations in Memory. Ed. Cathy Caruth. Baltimore: The Johns Hopkins UP, 1995. 3-12. Print.

Craps, Stef. "Beyond Eurocentrism: Trauma Theory in the Global Age" The Future of Trauma Theory: Contemporary Literary and Cultural Criticism. Ed. Gert Buelens, Samuel Durrant and Robert Eaglestone. London: Routledge, 2014. 45-62. Print.

Derry, Charles. Dark Dreams 2.0: A Psychological History of the Modern Horror Film from the 1950s to the $21^{\text {st }}$ Century. Jefferson, NC: McFarland, 2009. Print.

Die! Die! My Darling! Dir. Silvio Narizzano. Perf. Tallulah Bankhead, Stefanie Powers. Columbia Pictures Corporation/Hammer Film Productions, 1965. Film.

Elm, Michael, Kobi Kabalek, and Julia B. Köhne. "Introduction: The Horrors of Trauma in Cinema." The Horrors of Trauma in Cinema: Violence Void Visualization. Ed. Michael Elm, Kobi Kabalek and Julia B. Köhne. Newcastle upon Tyne: Cambridge Scholars, 2014. 1-29. Print.

Hardy, Phil. The Aurum Film Encyclopedia of Horror. London: Aurum, 1993. Print.

Hogle, Jerrold E. "History, Trauma and the Gothic in Contemporary Western Fictions." The Gothic World. Ed. Glennis Byron and Dale Townshend. London: Routledge, 2014. 72-81. Print. 
Kaplan, E. Ann. Trauma Culture: The Politics of Terror and Loss in Media and Literature. New Brunswick: Rutgers UP, 2005. Print.

"Ladies of the Grand Guignol. An Essay on Actress Exploitation Films of the 1960 and 1970s." Terrortrap.com. The Terror Trap. Web. 20 May 2019.

Lowenstein, Adam. Shocking Representation: Historical Trauma, National Cinema, and the Modern Horror Film. New York: Columbia UP, 2005. Print.

Mathijs, Ernest, and Jamie Sexton. Cult Cinema: An Introduction. Oxford: Wiley-Blackwell, 2011. Print.

Maxford, Howard. Hammer Complete: The Films, the Personnel, the Company. Jefferson, NC: McFarland, 2019. Print.

Morrison, James. "Shelley Winters: Camp, Abjection, and the Aging Star." Hollywood Reborn: Movie Stars of the 1970s. Ed. James Morrison. New Brunswick: Rutgers UP, 2010. 120-37. Print.

Muir, John Kenneth. Horror Films of the 1970s. Jefferson, NC: McFarland, 2002. Print.

Penner, Jonathan, Steven Jay Schneider, and Paul Duncan. Horror Cinema. N.p.: Taschen, 2008. Print.

Roche, David. "Exploiting Exploitation Cinema: An Introduction." Transatlantica. Revue d'études américaines/American Studies Journal [Online] 2 (2015): 1-18. PDF file.

Shelley, Peter. Grande Dame Guignol Cinema: A History of Hag Horror from "Baby Jane" to "Mother." Jefferson, NC: McFarland, 2009. Print. Smith, Gary A. Uneasy Dreams: The Golden Age of British Horror Films, 1956-1976. Jefferson, NC: McFarland, 2000. Print.

Whoever Slew Auntie Roo? Dir. Curtis Harrington. Perf. Chloe Franks, Shelley Winters. America International Productions, 1972. Film.

\footnotetext{
Tomasz Fisiak is Assistant Professor in the Department of Canadian, Intermedial and Postcolonial Studies, Institute of English Studies, University of Łódź. In 2014 he defended his PhD in which he analyzed the portraits of female tyrants in selected Gothic novels. $\mathrm{He}$ also holds an MA degree in International Gender Studies, Faculty of International and Political Studies, University of Łódź. Gothicism as a widely understood cultural phenomenon, as well as gender/queer issues, remain the main subjects of his research. He has published articles on feminist auto/biographies, horror cinema, and modern erotic fiction. tomasz.fisiak@uni.lodz.pl
} 